\title{
Tabulation of myeloid, lymphoid and intestinal malignancies in Crohn's disease
}

\author{
Hugh J Freeman MD
}

\author{
H Freeman. Tabulation of myeloid, lymphoid and intestinal \\ malignancies in Crohn's disease. Can J G astroenterol \\ 2002;16(11):779-784.
}

A variety of malignant complications occur in C rohn's disease, and previous studies have recorded an increased intestinal cancer risk. The present investigation tabulated myeloid and lymphoid malignancies compared with intestinal cancers in 1000 consecutively evaluated patients with Crohn's disease who were followed over an extended period by a single clinician. M yeloid and lymphoid neoplasms were present in $0.5 \%$ of patients, while cancer in the intestinal tract was detected in $1 \%$. M ost of these patients with a malignancy had C rohn's disease for a prolonged period of more than 20 years and had negative outcomes, including death or presentations with advanced disease. In this cohort, Iymphoma was not detected in a single patient after definition of C rohn's disease, possibly reflecting the limited use of immunosuppressives or infused biological agents in this clinical practice. Bypassed rectal 'stumps' were associated with subsequent colorectal cancer in half of all males with colon cancer in this series, suggesting an important risk factor following colectomy in Crohn's disease. Epithelial dysplasia was detected in only a single male patient before colorectal cancer, implying that this histopathological marker may be a poor predictor of subsequent colon cancer development in Crohn's disease, an inflammatory bowel disease process that is typically patchy or focal in distribution in the intestinal tract.

Key Words: Colon cancer; C rohn's disease; Immunosuppressives; Infliximab; Leukemia; M ultiple myeloma, Small intestinal cancer

\section{Fréquence des tumeurs myéloïdes, lymphoïdes et intestinales dans le contexte de la maladie de Crohn}

La maladie de Crohn (MC) est associée à différentes complications malignes, et des études ont déjà fait état d'un risque accru de cancer de l'intestin. La présente recherche porte sur la fréquence des tumeurs myéloïdes et lymphoïdes par rapport à celle des cancers de l'intestin chez 1000 patients consécutifs, atteints de la MC et suivis sur une longue pério de par un même clinicien. Les néoplasmes myéloïdes et lymphoïdes étaient présents chez $0,5 \%$ des patients, tandis qu'un cancer de l'intestin a été décelé chez $1 \%$ d'entre eux. La plupart des patients touchés souffraient de la MC depuis au moins 20 ans et avaient connu une évolution défavorable, y compris la mort ou une maladie rendue à un stade avancé. A ucun lymphome $n$ 'a été décelé dans la cohorte après la confirmation du diagnostic de la MC, ce qui pourrait s'expliquer par le recours limité aux immunosuppresseurs et aux agents biologiques en perfusion dans la pratique clinique. Les moignons pontés de rectum ont été associés à l'apparition ultérieure d'un cancer colorectal chez la moitié de tous les hommes souffrant d'un cancer du côlon dans la présente série, ce qui donne à penser à l'existence d'un important facteur de risque à la suite d'une colectomie dans le contexte de la M C. U n seul cas de dysplasie épithéliale a été décelé chez un patient masculin avant l'apparition d'un cancer colorectal; ce marqueur histopathologique se montrerait donc un faible prédicteur de I'apparition ultérieure d'un cancer du côlon dans le contexte de la MC, maladie inflammatoire de l'intestin qui se caractérise par une atteinte régionale ou focale du tube digestif.

D epartment of M edicine ( $G$ astroenterology), U niversity of B ritish C olumbia, Vancouver, B ritish C olumbia

C orrespondence and reprints: Dr H ugh F reeman, A C U F-137, U niversity of B ritish C olumbia H ospital, 2211 W esbrook M all, Vancouver,

B ritish C olumbia V 6T 1W 5. Telephone 604-822-7216, fax 604-822-7236

Received for publication July 9, 2002. A ccepted September 11, 2002 
nvestigations have recorded an increased intestinal cancer risk in Crohn's disease (1-3), including some cohort and population based studies from $C$ anada, where reporting of malignant diseases is legally required $(4,5)$. A scertainment has been based on multiple sources, including physician notifications, pathology, hospitalizations, mortality and autopsy records $(4,5)$. 0 ther literature reports have also described both myeloid and lymphoid malignancies in Crohn's disease (3,5-16).

In 1979, G reenstein et al (6) described an excess of lymphomas in 1227 patients with Crohn's disease thought to be related to associated immunological deficiencies, use of immunosuppressive medications, or increased exposure to ionizing radation. In 1982, $\mathrm{H}$ anauer et al (7) reported the presence of leukemia in Crohn's disease. Later, additional cases of Crohn's disease with either myeloid or lymphoid malignancies, including both Hodgkin's and nonH odgkin's lymphoma, were recorded (8-14). Finally, rare cases of multiple myeloma have been noted $(15,16)$. M ore recent studies related to risk in Crohn's disease, particularly for Iymphoma, appear to differ in their conclusions, but concerns have been expressed related to the use of immunosuppressives (13) as well as infused biological agents (9), both having been hypothesized to play a role in Iymphoma pathogenesis. Some of the difficulty related to assessing the risk of lymphoma and other hematological malignancies in Crohn's disease may reflect the following: methods of data collection (eg, multiphysician teaching hospital cohort studies versus administrative coding based diagnoses in population studies) and data expression; precision of the initial diagnosis, especially of C rohn's disease; duration of clinical follow-up; and differing methods of treatment, including the frequency of intestinal resection.

For over two decades, a single clinician database of 1000 consecutive patients with $\mathrm{C}$ rohn's disease has been developed with extensive follow-up, averaging over 10 years. This population was defined previously as femalepredominant $(56.1 \%)$, diagnosed most often before age 40 $(84.4 \%)$ and more than $95 \%$ born in Canada (17). Most had ileal and/or colonic involvement with stenosing or penetrating complications of Crohn's disease (17) and almost half required an earlier intestinal resection. In the present report, the results of a prospectively tabulated list of myeloid and lymphoid malignancies, along with intestinal cancers, are detailed. Of note, this cohort appeared to be 'pharmacologically-naive' because only about $10 \%$ were treated with a nonsteroid immunosuppressive medication or a newer infused 'biological' agent.

\section{MATERIALS AND METHODS}

One thousand consecutive patients with Crohn's disease were evaluated. A II patients were seen directly by the author, and a diagnosis of Crohn's disease was established based on defined criteria (18). U sually, endoscopic biopsy specimens or surgically-resected intestinal materials were available for review. For some referred patients with an already established diagnosis, endoscopic, operative and
TABLE 1

Treatments for Crohn's disease ${ }^{\star}$

\begin{tabular}{|c|c|}
\hline Treatment & Number \\
\hline 5-ASA & 701 \\
\hline 5-ASA alone & 181 \\
\hline Steroids ${ }^{\dagger}$ & 531 \\
\hline Metronidazole & 296 \\
\hline \multicolumn{2}{|c|}{ Immunosuppressants (nonsteroid) } \\
\hline Aza/6-MP & 99 \\
\hline Cyclosporine & 7 \\
\hline Methotrexate & 11 \\
\hline \multicolumn{2}{|l|}{ Biological agents } \\
\hline Infliximab ${ }^{\dagger}$ & 5 \\
\hline ISIS $2302^{\dagger}$ & 1 \\
\hline $\mathrm{IL}-10^{\dagger}$ & 1 \\
\hline Surgical resection & 441 \\
\hline
\end{tabular}

${ }^{*} n=1000$. Most patients required more than one form of treatment.

tSome received oral budesonide in a published clinical trial (19); others received infliximab (20), ISIS 2302 (21) or IL-10 (22) in clinical trials or compassionate release through another physician. 5-ASA 5-Aminosalicylic acid; Aza Azathioprine, 6-MP 6-mercaptopurine; ISIS 2302 antisense drug, Isis Pharmaceuticals, USA; IL-10 Interleukin 10

pathological reports were available. In some, but not all patients, tissue section materials were available. In this prospective database, treatments administered were recorded, including medications and intestinal resections. Reporting malignant disease is legally required in British C olumbia and linkage on progress with treatment is provided to referring physicians.

A small number of patients (less than $0.3 \%$ ) in this database had received medication in a multicentre clinical trial (19) or on a compassionate basis through an investigator at another university teaching centre (20-22). For the purposes of this evaluation, medications were classified as a 5A minosalicyclic acid (5-A SA) or steroids, without reference to the specific corporate tradename, route or dose of administration. Table 1 lists the differing treatments for this cohort. Almost half of the patients in this series required an intestinal resection (44.1\%). M ost received a 5A SA medication or a corticosteroid. A bout $10 \%$ also received a nonsteroid immunosuppressive (ie, azathioprine, 6-mercaptopurine, cyclosporine, methotrexate) or a biological form of treatment, similar to the rates of use reported elsewhere for an other $C$ anadian province (5), but less than reported use rates of up to $30 \%$ in A merican and European referral-based centres $(11,13,23)$.

RESU LT S

\section{Myeloid and lymphoid malignanices}

$M$ yeloid and lymphoid malignancies were detected in $0.5 \%$ (ie, five/1000) of the patients with C rohn's disease seen in this largely referral-based population and followed for a 
mean period of more than 10 years. A Ithough low, this figure markedly exceeds the combined cumulative agestandardized annual incidence rates for myeloid leukemia (males 35.6; females 28.0), lymphoid leukemia (males 47.7; females 29.0) and multiple myeloma (males 46.2; females 31.9) previously reported in the British Columbia population for the 10-year period of 1990 to 1999, inclusive (expressed per 100,000) (12). Of these, no patient had received an immunosuppressive medication (ie, azathioprine, 6-mercaptopurine, cyclosporine, methotrexate) or a biological agent. In one patient, H odgkin's disease was diagnosed more than 10 years before the detection of Crohn's disease, and, therefore, was not considered an incident case complicating the course of the C rohn's disease. In one other patient, a diagnosis of myelogenous leukemia was made after the diagnosis of C rohn's disease but within one year, and might be considered a 'concurrent diagnosis'. Thus, if these two cases were excluded from the 'incidence' calculation of established disease, $0.3 \%$ or three/ 1000 may be a more precise incidence estimate. To date, in the present cohort of 1000 patients with C rohn's disease followed over an extended period (mean of more than 10 years) by a single clinician, there were no observations of a patient with a nonH odgkin's lymphoma.

Tables 2 and 3 detail the characteristics of the Crohn's disease in five patients with a myeloid or lymphoid malignancy, as well as their outcomes. Except for the woman diagnosed with Crohn's disease more than a decade after successful treatment of Hodgkin's disease, the other four patients were men and were diagnosed with C rohn's disease at a relatively older age compared with the previously published age of diagnosis (before age 40 years in more than $80 \%$ ) in this C rohn's disease patient population (17). A II of these male patients with Crohn's disease died, usually two

TABLE 2

Characteristics of Crohn's disease in myeloid and lymphoid malignancies ${ }^{\star}$

\begin{tabular}{lclll}
\hline Sex, age (years) ${ }^{\dagger}$ & Year diagnosed & Disease site & Behaviour & Treatment \\
\hline $\begin{array}{l}\text { Myelogenous leukemia } \\
\text { Male, } 54\end{array}$ & 1973 & lleum only & Stricturing \\
Male, 55 & 1981 & Colon only & NS/NP & SP/5-ASA, steroids, ileocolic resection \\
$\begin{array}{l}\text { Lymphocytic leukemia } \\
\text { Male, } 59\end{array}$ & 1985 & Colon only & NS/NP & SP \\
$\begin{array}{l}\text { Multiple myeloma } \\
\text { Male, 36 }\end{array}$ & 1959 & lleum only & Stricturing & SP \\
$\begin{array}{l}\text { Hodgkin's lymphoma }{ }^{\ddagger} \\
\text { Female, 20 }\end{array}$ & 1972 & lleum and colon & Penetrating & SP, ileocolic resection \\
& & & SP/5-ASA, steroids, metronidazole, \\
\end{tabular}

${ }^{*} n=5$, or $0.5 \%$ of 1000 patients with Crohn's disease. ${ }^{\dagger}$ Age at diagnosis of Crohn's disease.

$¥$ In the only patient with a diagnosed lymphoma, Hodgkin's disease was defined at age 10, about a decade before diagnosis of Crohn's disease and not included in calculation of incidence rate. No patient with a nonHodgkin's lymphoma was detected. NP Nonpenetrating; NS Nonstricturing; SP Sulfasalazine; SP/5ASA Sulfasalazine/5-Aminosalicylic acid; TPN Total parenteral nutrition

TABLE 3

Outcomes of myeloid and lymphoid malignancies in Crohn's disease

\begin{tabular}{|c|c|c|c|c|}
\hline$\overline{\text { Sex, age (years) }}{ }^{\star}$ & Year diagnosed & Duration $^{\dagger}$ & Chemotherapy and/or radiation & Deceased \\
\hline \multicolumn{5}{|c|}{ Myelogenous leukemia } \\
\hline Male, 75 & 1994 & 21 years & Yes & Yes \\
\hline Male, 55 & 1981 & 8 months & No & Yes \\
\hline \multicolumn{5}{|l|}{ Multiple myeloma } \\
\hline Male, 66 & 1989 & 30 years & Yes & Yes \\
\hline \multicolumn{5}{|c|}{ Lymphocytic leukemia } \\
\hline Male, 68 & 1994 & 9 years & No & Yes \\
\hline \multicolumn{5}{|c|}{ Hodgkin's lymphoma } \\
\hline Female, 10 & 1962 & $\ddagger$ & Yes & No \\
\hline
\end{tabular}

${ }^{*}$ Age of diagnosis of hematologic or lymphoproliferative malignancy. ${ }^{\dagger}$ Duration of Crohn's disease before diagnosis of malignancy.

¥Female with Hodgkin's disease diagnosed at age 10 years while Crohn's disease diagnosed at age 20 years and not included in calculation of incidence rate 
or more decades after the diagnosis of C rohn's disease was established. In one case, a myelodysplastic syndrome (24) predated frank acute myeloid leukemia followed by a progressive rapid downhill clinical course and death only one year after the diagn osis of C rohn's disease.

\section{Intestinal malignancies}

Tables 4 and 5 detail the characteristics of Crohn's disease in 10 patients who developed an intestinal malignancy and their outcomes. Although most were men, an intriguing finding in this cohort was that women had intestinal adenocarcinomas detected in the small intestine or proximal transverse colon while men only had cancers detected distally in the rectum, most often in rectal stump mucosa. Of these 10 patients, only two men who developed rectal cancer had received azathioprine. M ost developed an intestin- al malignant complication after about two or more decades with Crohn's disease, although in one case, the diagnosis of a small bowel adenocarcinoma was established within a year of diagnosis of C rohn's disease. Despite recognition of increased predisposition to cancer in the small intestine and colon in Crohn's disease, a significant number (ie, $40 \%$ ) in this series al ready had advanced disease (eg, nodes, liver) at the time of their initial diagnosis of colon cancer. Of those with colon cancer, most were young men with rectal cancer, and of these, half were located in a rectal stump. One patient's malignant disease presented initially with a dramatic rectal perforation and metastatic disease in the liver despite a previous colonoscopy with negative multiple site colonic biopsies for dysplasia within the year before death.

\section{TABLE 4}

Characteristics of Crohn's disease in intestinal malignancies ${ }^{*}$

\begin{tabular}{lclll}
\hline Sex, age & \multicolumn{1}{l}{ Year diagnosed } & Disease site & Behaviour & Treatment \\
\hline Colonic adenocarcinoma & & & & \\
Male, 29 & 1965 & Colon only & NS/NP & SP/5-ASA \\
Male, 24 & 1968 & lleum and colon & Penetrating & SP/5-ASA, Aza, ileocolonic resections \\
Male, 29 & 1983 & Colon only & Penetrating & SP, steroids, TPN \\
Male, 30 & 1967 & lleum and colon & Penetrating & Subtotal colectomy, ileocolonic resection \\
Male, 30 & 1965 & Colon only & NS/NP & SP \\
Male, 24 & 1958 & Colon only & Penetrating & Steroids, Aza, Partial colectomy \\
Female, 32 & 1981 & lleum and colon & Stricturing & 5-ASA, steroids, ileocolonic resection \\
Small bowel adenocarcinoma & & & & \\
Female, 32 & 1983 & lleum and colon & Stricturing & 5-ASA, ileocolonic resection \\
Female, 21 & 1977 & lleum and colon & Penetrating & 5-ASA, steroids, ileocolonic resection \\
Female, 61 & 1977 & lleum and colon & Penetrating & Ileocolonic resection
\end{tabular}

${ }^{*} n=10$ or $1 \%$ of 1000 patients with Crohn's disease 'Age at diagnosis of Crohn's disease and year of diagnosis of Crohn's disease. 5-ASA 5-Aminosalicylic acid; Aza Azathioprine; NP Nonpenetrating; NS Nonstricturing; SP Sulfasalazine; SP/5-ASA Sulfasalazine/5-Aminosalicylic acid; TPN Total Parenteral Nutrition

TABLE 5

Outcomes of intestinal malignancies in Crohn's disease

\begin{tabular}{|c|c|c|c|c|}
\hline$\overline{\text { Sex, age }}{ }^{\star}$ & Year diagnosed $^{\dagger}$ & Duration & Location/metastases/type & Treatment \\
\hline \multicolumn{5}{|c|}{ Colonic adenocarcinoma } \\
\hline Male, 59 & 1995 & 30 & Rectum, nodes, adenoca & APR/rad-chem \\
\hline Male, 46 & 1990 (died 1992) & 22 & Rectal stump, nodes and lungs, mucinous adenoca & APR/rad-chem \\
\hline Male, 36 & 1990 (died 1990) & 7 & Rectum (perforation), liver, adenoca & None \\
\hline Male, 48 & 1985 & 18 & Rectal stump, adenoca & APR/rad \\
\hline Male, 50 & 1986 & 20 & Rectum, adenoca & Low ant resection \\
\hline Male, 54 & 1998 & 40 & Rectal stump, adenoca and squamous cell cancer & APR/rad-chem \\
\hline Female, 52 & 2001 & 20 & Trans colon, adenoca & Ileocolic resection \\
\hline \multicolumn{5}{|c|}{ Small bowel adenocarcinoma } \\
\hline Female, 50 & 2001 & 18 & Ileum adenoca; liver metastases & Ileocolic resection \\
\hline Female, 26 & 1982 & 5 & Ileum adenoca & Ileocolic resection \\
\hline Female, 61 & 1977 & 1 & Ileum adenoca & Ileocolic resection \\
\hline
\end{tabular}

*Age of carcinoma diagnosis. ${ }^{+}$Year of diagnosis of carcinoma; for female with diagnosis in 1977, Crohn's disease diagnosed 10 months earlier in the same year APR Abdominoperineal resection surgery; rad-chem radiation and chemotherapy 


\section{D ysplasia in colorectal biopsies}

A Ithough no patient had systematic surveillance colonoscopies and biopsies, all 14 patients (excluding the Hodgkin's disease patient) had multiple site colonic biopsies before the diagnosis of malignancy, and most had undergone multiple endoscopic procedures (total 32) each with multiple biopsies, in some instances by other expert clinicians in other centres during the previous five years. This investigation was not designed to systematically evaluate the role of surveillance and multisite biopsy in the detection of cancer or 'precancer' in Crohn's disease. However, it is noteworthy that in the course of a routine, albeit focused, clinical practice, only a single patient had dysplastic changes in one colorectal biopsy detected before a diagnosis of invasive intestinal cancer. Subsequent pathological review of all endoscopic colorectal biopsies done before the detection of intestinal cancer (with the knowledge of intestinal cancer development) in 14 patients failed to reveal any additional biopsy specimens with dysplasia, in spite of the distal location of the cancers in most of these patients with Crohn's disease. In addition, all colonic biopsies done in most patients in this group after the diagnosis and treatment of malignancy were also negative for dysplasia or malignancy.

\section{DISC U SSION}

This study enumerated myeloid and lymphoid malignancies in a single clinician database for Crohn's disease, defined prospectively during a period of over 20 years, and compared these with intestinal cancers. In this cohort with extensive follow-up averaging over 10 years, five patients had a myeloid or lymphoid malignancy $(0.5 \%)$ and 10 developed an intestinal carcinoma (1\%), all exceeding the rates for British Columbia (12). Of note, in the present study, Crohn's disease was never observed to be complicated by lymphoma, although H odgkin's disease was detected a decade before $C$ rohn's disease in a single patient. $G$ iven the author's personal experience with the detection of lymphoma (25-31), including those observed to complicate another intestinal disorder, celiac disease, the complete absence of a lymphoma complicating the clinical course in a large cohort of C rohn's disease seemed surprising. These results, however, concurred with an extensive evaluation of a large general practice population database from the U nited Kingdom where no increased risk of lymphoma was seen in Crohn's disease, but concern related to nonsteroidal immunosuppressive use as a risk factor for lymphoma was expressed (11). Similarly, lymphomas were recorded after the use of infused biological agents, such as infliximab (9), while immunosuppressive use was associated with a low but real risk of lymphoma in inflammatory bowel disease (13). In this series, the complete absence of lymphoma, therefore, might simply reflect the limited use of immunosuppressive medications (excluding steroids) and infused biological agents in this clinical practice.

The present report contrasts the findings in another larger population based Canadian study that showed an increased lymphoma risk in males with Crohn's disease, even though the patient characteristics appeared similar and the frequency of immunosuppressive use in both groups was historically limited (5). This may reflect the inherent limitations of administrative databases that use coded diagnoses rather than data based on direct physician contact and follow-up. Erroneous initial coding for C rohn's disease could lead to the conclusion that Crohn's disease was complicated (rather than mimicked) by lymphoma during a later hospitalization. A Iternatively, a patient with Crohn's disease or a complication (eg, perianal abscess, fistula) might be coded with a less specific code and not included in a database, affecting incidence data. Coding based primarily on hospital data may reflect a more active or refractory disease phenotype, or result in Berkson's bias, a form of detection bias. In the present study, these forms of data collection bias were largely avoided, in part related to the extended period of follow-up by a single clinician and the legal provincial requirement for notification of malignant disease. A Iternatively, if the experience in the treatment of rheumatoid arthritis or organ transplantation is considered (32-35), immunosuppressive dose or duration of use may be important, especially if prolonged. Future studies may help to further elucidate these issues in C rohn's disease patients, particularly if maintenance treatment is contemplated.

The present study also enumerated the intestinal cancers seen in $10 \mathrm{Crohn}$ 's disease patients in this study (1\%). The clinical features of the intestinal cancers were similar to those noted in earlier studies, including: the long history of Crohn's disease, often over 20 years predating cancer; the relatively young age of intestinal cancer diagnosis in C rohn's disease; and the appearance of other histopathological types, including mucinous adenocarcinoma (4). In this series, cancers were also detected in bypassed or excluded segments of intestine (ie, rectal 'stump' cancer), a potentially important risk factor following colonic resection. Interestingly, in this study, there was a predilection for proximal intestinal cancer in females compared with more distal colorectal cancer in males. Although data on the effects of endogenous sex hormones and their potential effects on the subsite distribution of colon cancer are very limited (35), the findings here raise the possibility that sex hormones may play a role in the distribution of cancers along the length of the intestinal tract in younger patients with Crohn's disease complicated by malignant disease. Further studies on the effects of commonly used estrogen formulations and hormone replacement therapies in Crohn's disease are needed.

The outcome for patients with a malignancy in Crohn's disease, based on this limited experience, has been disconcerting. A II patients diagnosed with a myeloid or lymphoid malignancy in this series, and most with an intestinal cancer complicating the course of Crohn's disease, either died or currently have advanced disease. In Crohn's disease, epithelial dysplasia occurs in the small and large intestine, which supports the concept of a dysplasia-carcinoma sequence in Crohn's disease (36), but also highlights that 
most cases of carcinoma in Crohn's disease are detected, even in large tertiary referral centres, incidentally at surgery (37). U nfortunately, specific recommendations for screening and surveillance colonoscopy even in chronic extensive Crohn's colitis have been supported by only very limited data in older patients (38). The present report fails to provide support for systematic surveillance to detect epithelial dysplasia as a 'precancer' marker in Crohn's disease. A Ithough a formal program of surveillance was not done in this population, all patients had endoscopic studies with biopsies. In this series, epithelial dysplasia was observed in one endoscopic biopsy in only a single patient before the diagnosis of colon cancer. Even subsequent review of these

\section{REFEREN CES}

1. Weedon DD, Shorter RG, Ilstrup DM , H uizenga KA, Taylor W F Crohn's disease and cancer. N Engl J M ed 1973;289:1099-103.

2. Gyde SN, Prior P, M acC artney JC, Thompson H, W aterhouse JA H, A llan R N. M alignancy in Crohn's disease. G ut 1980;21:1024-9.

3. Freeman HJ. N eoplastic complications of inflammatory bowel disease. In: Freeman HJ, ed. Inflammatory Bowel Disease, vol 2. Boca Raton: CRC Press, 1989:23-5.

4. Freeman HJ. Colorectal cancer complicating Crohn's disease. C an J Gastroenterol 2001;15:231-6.

5. Bernstein CN, Blanchard JF, Kliewer E, W ajda A . C ancer risk in patients with inflammatory bowel disease. A population-based study. Cancer 2001;91:854-62.

6. Greenstein A J, G ennuso R, Sachar DB, et al. Extraintestinal cancers in inflammatory bowel disease. Cancer 1985;15:2914-21.

7. H anauer SB, W ong KK, Frank PH, Sweet DL, Kirsner JB. A cute leukemia following inflammatory bowel disease. Dig Dis Sci 1982;27:545-8

8. M ir M adjlessi SH, Farmer RG, W eick JK. Inflammatory bowel disease and leukemia. A report of seven cases of leukemia in ulcerative colitis and Crohn's disease and review of the literature. Dig Dis Sci 1986;31:1025-31.

9. Bickston SJ, Lichtenstein GR, A rseneau KO, C ohen RB, Cominelli $F$. The relationship between infliximab treatment and lymphoma in Crohn's disease. G astroenterology 1999;117:1433-7.

10. Loftus EV Jr, Tremaine W J, H abermann T M , H armsen W S, Zinsmeister A R, Sandborn W J. Risk of lymphoma in inflammatory bowel disease. A m J G astroenterol 2000;95:2308-12.

11. Lewis JD, Bilker W B, Brensinger C, Deren JJ, Vaughn DJ, Strom BL. Inflammatory bowel disease is not associated with an increased risk of lymphoma. G astroenterology 2001;121:1080-7.

12. A ge-standardized incidence rates for cancer, $B C$ C ancer Statistics, A nnual Reports, 1991-2000. Vancouver: BC C ancer A gency.

13. Farrell RJ, Ang Y, Kileen $P$, et al. Increased incidence of nonHodgkin's lymphoma in inflammatory bowel disease patients on immunosuppressive therapy but overall risk is low. G ut 2000;47:514-9.

14. Kumar S, Fend F, Q uintanilla-M artinez $L$, et al. Epstein-Barr viruspositive primary gastrointestinal Hodgkin's disease: association with inflammatory bowel disease and immunosuppression. A m J Surg Pathol 2000;24:66-73.

15. M inami $A$, I wai $A, W$ atanabe $Y$, et al. Two cases of inflammatory bowel disease with multiple myeloma. J G astroenterol 1999;34:629-33.

16. Hara T, O zaki S, Kosaka M, et al. Biclonal lymphoplamacytic immunocytoma associated with C rohn's disease. Intern M ed 1999;38:500-3.

17. Freeman HJ. A pplication of the Vienna Classification for C rohn's disease to a single clinician database of 877 patients. Can J Gastroenterol 2001;15:89-93.

18. Lennard-Jones JE. Classification of inflammatory bowel disease. Scand J G astroenterol 1989:170(Suppl):2-6.

19. G reenberg $G R$, Feagan $B G, M$ artin $F$, et al. 0 ral budesonide for active Crohn's disease. N Engl J M ed 1994;331:836-41.

20. Targan SR, H anauer SB, van Deventer SJ, et al. A short-term study of chimeric monoclonal antibody CA 2 to tumor necrosis factor al pha for Crohn's disease. N Engl J M ed 1997;337:1029-35. earlier endsocopic biopsies, despite knowledge of a cancer diagnosis, did not increase the yield of dysplasia detection and dysplasia was not detected in subsequent endoscopic biopsies after diagnosis of cancer in these patients with $\mathrm{C}$ rohn's disease. C onceivably, because of the focal nature of dysplastic change in most cases of inflammatory bowel disease in general, and even more so in Crohn's disease, a disorder with a normally patchy distribution, the likelihood of establishing a productive program of screening for epithelial dysplasia or focal neoplasia in C rohn's disease is low. 0 ther, more reliable predictive tools, possibly molecular or genetic markers that might predict future intestinal cancer in Crohn's disease, are needed

21. Yacyshyn BR, Bowen-Yacyshyn M B, Jewell L, et al. A placebocontrolled trial of ICA M-1 antisense oligonucleotide in the treatment of C rohn's disease. G astroenterology 1998;114:1133-42.

22. Fedorak RN, $G$ angl A, Elson C $O$, et al. Recombinant human interleukin 10 in the treatment of patients with mild to moderately active C rohn's disease. G astroenterology 2000;119:1473-82.

23. Dayharsh GA, Loftus EV Jr, Sandborn W J, et al. Epstein-Barr viruspositive lymphoma in patients with inflammatory bowel disease treated with azathioprine or 6-mercaptopurine. G astroenterology 2002;122:72-7.

24. H arewood G C, Loftus EV, Tefferi A, Tremaine W J, Sandborn WJ. Concurrent inflammatory bowel disease and myelodysplastic syndromes. Inflamm Bowel Dis 1999;5:98-103.

25. Freeman HJ, W einstein W M , Shnitka TK, Piercey JR, W ensel RH Primary abdominal lymphoma. Presenting manifestation of celiac disease or complicating dermatitis herpetiformis. A $\mathrm{m} \mathrm{J} \mathrm{M} \mathrm{ed}$ 1977;63:585-94.

26. Freeman HJ, Chiu BK. M ultifocal small bowel lymphoma and latent celiac sprue. G astroenterology 1986;90:1992-7.

27. Freeman HJ, Chiu BK. Small bowel malignant lymphoma complicating celiac sprue and the mesenteric lymph node cavitation syndrome. G astroenterology 1986;90:2008-12.

28. Freeman HJ. N eoplastic disorders in 100 patients with celiac disease. Can J Gastroenterol 1996;10:163-6.

29. Freeman HJ. Fulminant liver failure with necrotizing foci in the liver, spleen and lymph nodes in celiac disease due to malignant Iymphoma. C an J Gastroenterol 1996;10:225-9.

30. Freeman $\mathrm{HJ}$. M antle cell lymphoma of the gastrointestinal tract (Iymphomatous polyposis). C an J G astroenterol 1996;10:144-8.

31. Freeman HJ, A nderson MD, G ascoyne RD. Clinical, pathologic and molecular genetic findings in small intestinal follicle center cell Iymphoma. Can J G astroenterol 1997;11:31-4.

32. W ilkinson A H, Smith JL, H unsicker LG, et al. Increased frequency of posttransplant lymphomas in patients treated with cyclosporine, azathioprine, and prednisone. Transplantation 1989;47:293-6.

33. Silman A J, Petrie J, H azleman B, Evans SJ. Lymphoproliferative cancer and other malignancy in patients with rheumatoid arthritis treated with azathioprine: a 20 year follow up study. A nn Rheum Dis 1988;47:988-92.

34. A sten P, M arrett J, Symmons D. Risk of developing certain malignancies is related to duration of immunosuppressive drug exposure in patients with rheumatic diseases. J R heumatol 1999;26:1705-14

35. Yoo KY, Tajima K, Inoue M, et al. Reproductive factors related to the risk of colorectal cancer by subsite: a case-control analysis. $\mathrm{Br}$ J Cancer 1999;79:1901-6.

36. Petras RE, M adjlessi SH, Farmer RG . C rohn's disease and intestinal carcinoma. A report of 11 cases with emphasis on associated epithelial dysplasia. Gastroenterology 1987:93:1307-14.

37. Sigel JE, Petras RE, Lashner BA, Fazio VW, G oldblum JR. Intestinal adenocarcinoma in Crohn's disease: a report of 30 cases with a focus on coexisting dysplasia. A m J Surg Pathol 1999;23:651-5.

38. Friedman S, Rubin PH, Bodian C, Goldstein E, Harpaz N, Present DH. Screening and surveillance colonoscopy in chronic Crohn's colitis. G astroenterology 2001;120:820-6. 


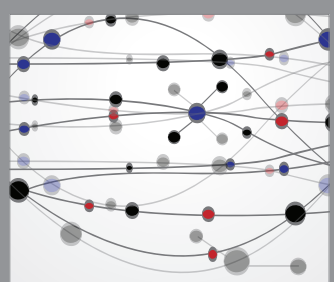

The Scientific World Journal
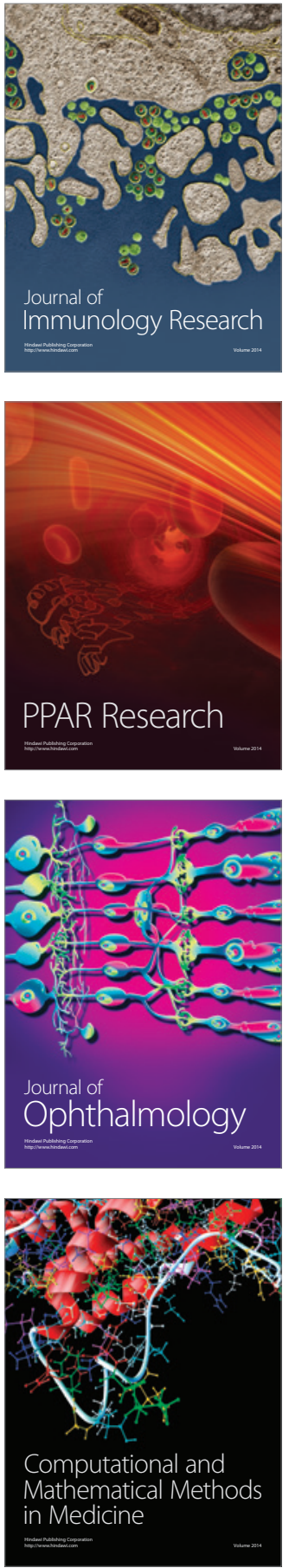

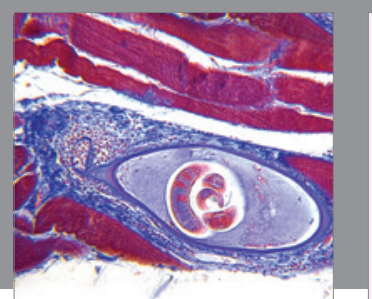

Gastroenterology Research and Practice

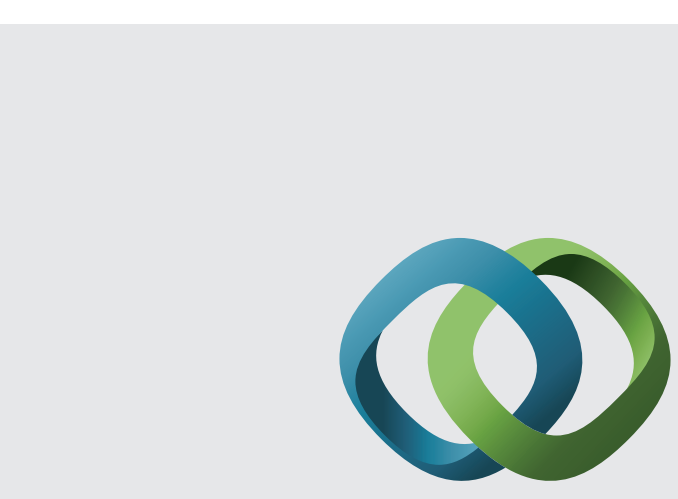

\section{Hindawi}

Submit your manuscripts at

http://www.hindawi.com
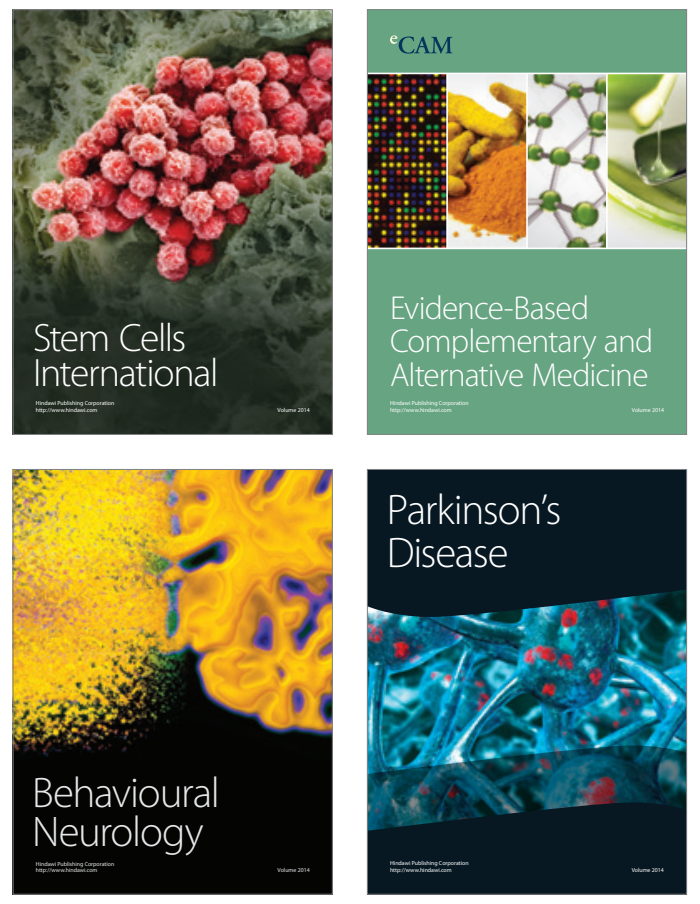
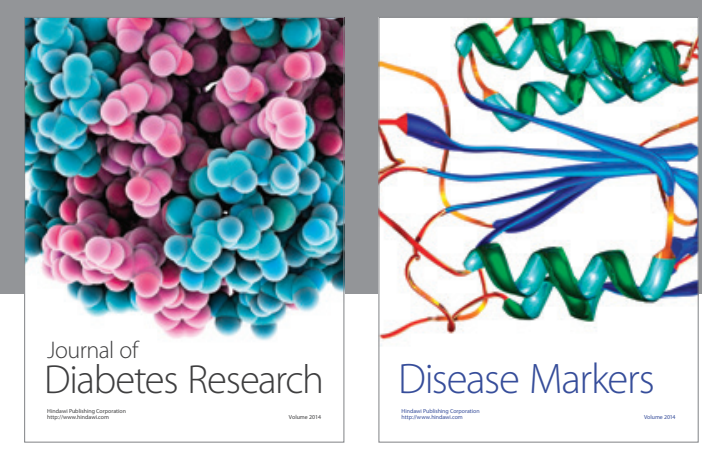

Disease Markers
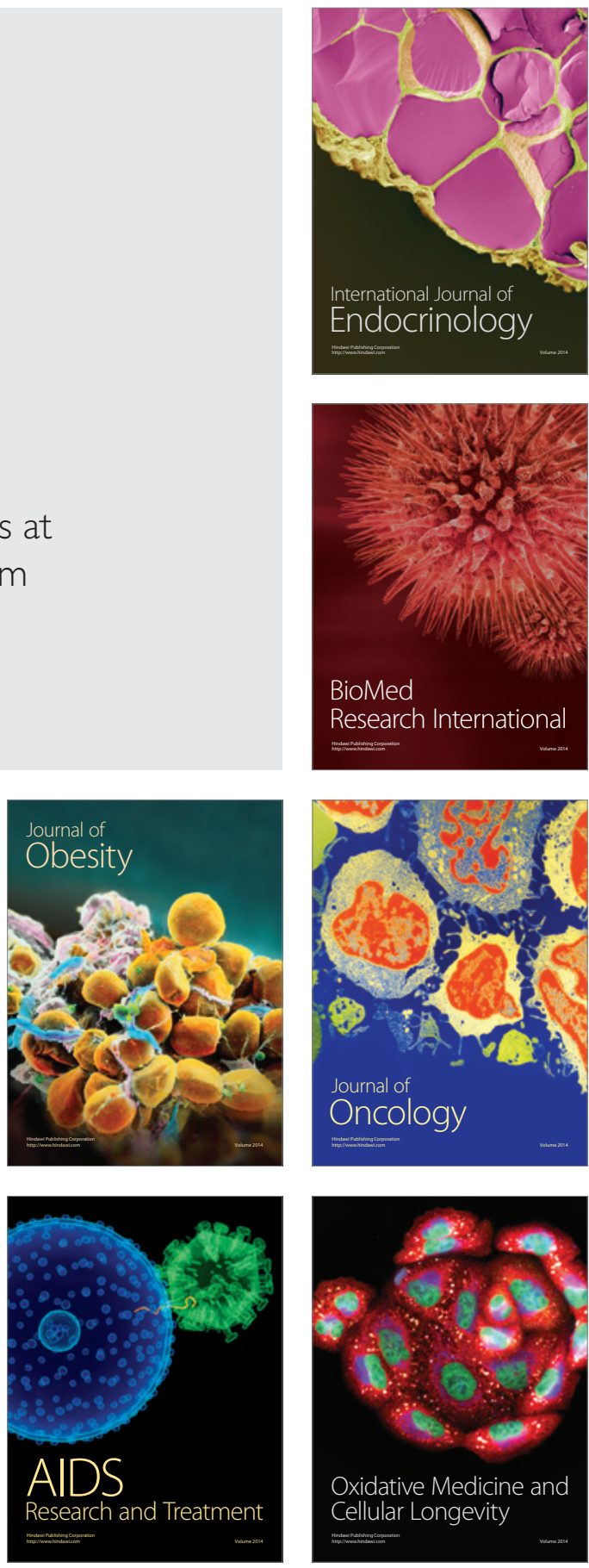